
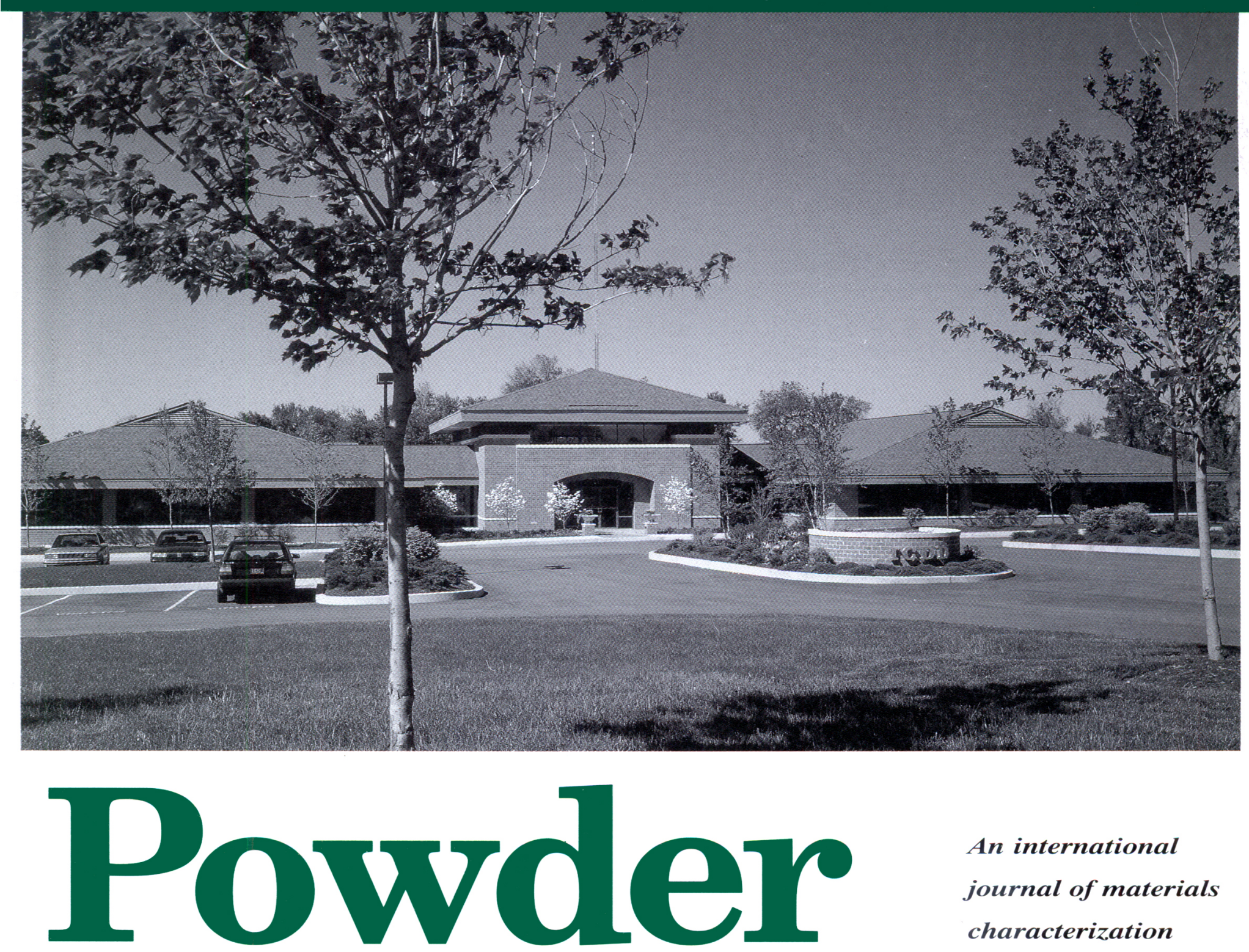

An international journal of materials characterization

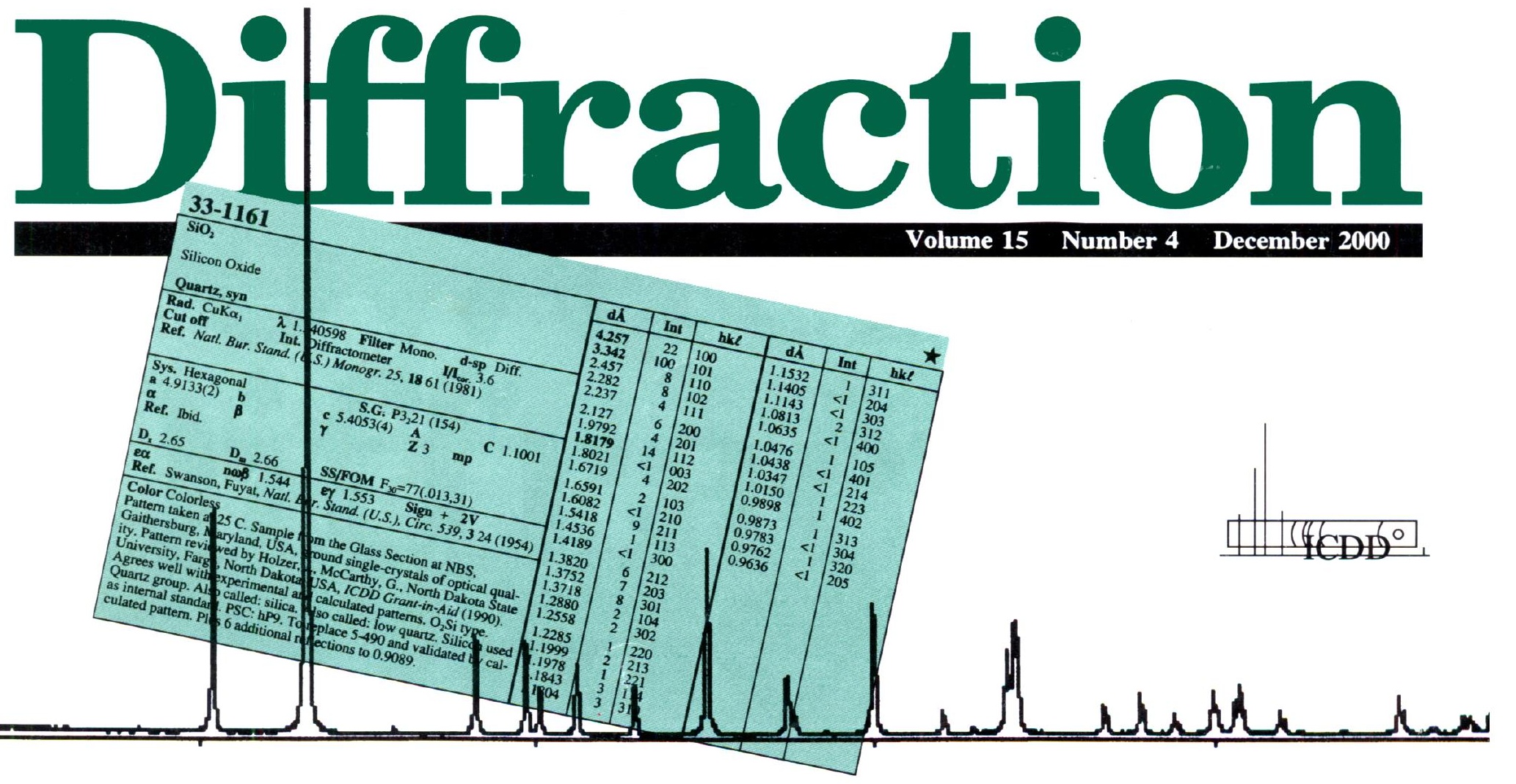




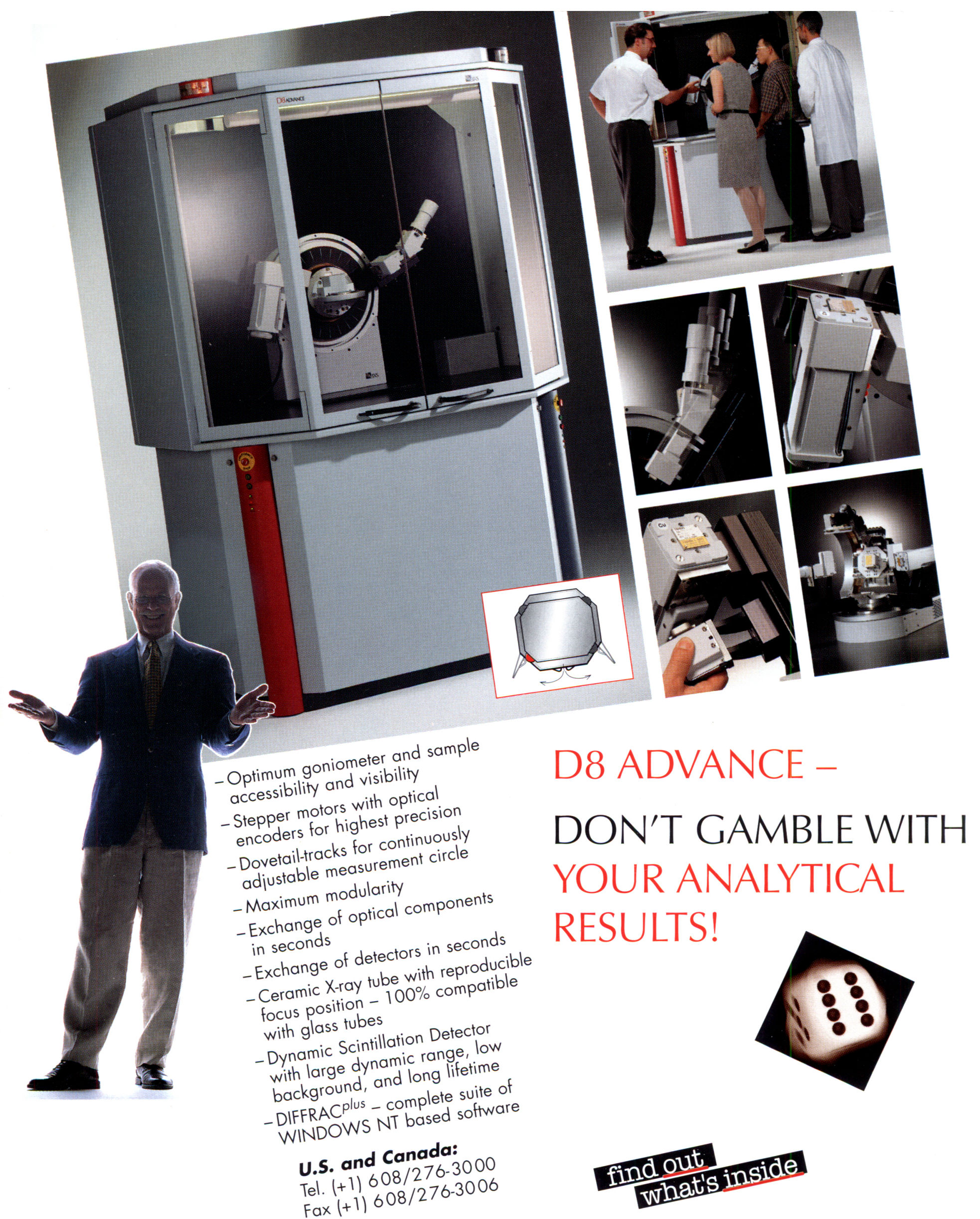




\section{X-ray diffraction}

for today

\section{and tomorrow}

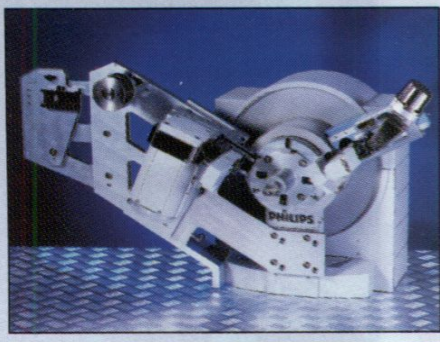

The inevitability of change has long been recognized and the pace of change is accelerating at an ever increasing rate. This is true in the laboratory domain as in every other aspect of modern life. What you require from your X-ray diffractometer could be a world apart from your expectations today.

The Philips X'Pert PRO diffractometer system is an X-ray diffraction system with a virtually limitless capacity to adapt to changing circumstances. the PreFIX (Pre-aligned, Fast-Interchangeable XRay optics) system enables instruments to be reconfigured in a few minutes to handle different types of analysis.

A totally open design architecture guarantees full freedom to accommodate further advances in years to come.

For more information: Philips Analytical Lelyweg 1,7602 EA, Almelo, The Netherlands Tel. : +31 (546) 534444 Fax : +31 (546) 534592 www.analytical.philips.com 
An International Journal of Materials Characterization

\author{
Editor-in-Chief \\ Ting C. Huang \\ 6584 Radko Drive \\ San Jose, CA 95119-1924 U.S.A. \\ huang@icdd.com
}

\section{Managing Editor}

Shannon Mattaboni

JCPDS-International Centre for Diffraction Data 12 Campus Blvd.

Newtown Square, PA 19073-3273 U.S.A.

mattaboni@icdd.com

Editor for Reviews and Reprints

Deane K. Smith

1652 Princeton Drive

State College, PA 16803-3273 U.S.A.

smithdeane@aol.com

Editor for New Diffraction Data

William E. Mayo

Rutgers University

Ceramics Department

Piscataway, NJ 08855-0909 U.S.A

edisonjam@aol.com

\section{Western European Editor}

Norberto Masciocchi

Dipartimento di Scienze Chimiche

Fisiche e Matematiche

Università dell'Insubria

via Valleggio 11

22100 Como, Italy

e-mail: norbert@fis.unico.it

\section{Eastern European Editor}

Jaroslav Fiala

SKODA Research Ltd.

31600 Plzeń, Czech Republic

jaroslav.fiala@vsb.cz

Editor for Southeast Asia

Brian H. O'Connor

Curtin University

GPO Box U 1987, Perth 6001

Western Australia, Australia

toconnorb@cc.curtin.edu.au

Editor for Japan

Hideo Toraya

Ceramics Research Lab

Nagoya Institute of Technology

Asahigaoka, Tajimi 507 Japan

toraya@crl.nitech.ac.jp

International Reports Editor

Winnie Wong- $\mathrm{Ng}$

National Institute of Standards and Technology

100 Bureau Drive Stop 8520

Gaithersburg, MD 20899-8520 U.S.A.

winnie.wong-ng@ nist.gov

Editorial Advisory Board

P. Bayliss, Sydney, Australia

C. Z. Bojarski, Katowice, Poland

A. Brown, Dorset, England

D. Cox, Upton, New York

L. Frevel, Midland, Michigan

P. Gado, Budapest, Hungary

H. Goebel, Munchen, Germany

R. Jenkins, Newtown Square, Pennsylvania

G. G. Johnson Jr., State College, Pennsylvania

Q. Johnson, Livermore, California

J. I. Langford, Birmingham, U.K.

D. Louër, Rennes, France

G. J. McCarthy, Fargo, North Dakota

H. F. McMurdie, Gaithersburg, Maryland

M. E. Mrose, Gaithersburg, Maryland

M. Nichols, Livermore, California

R. L. Snyder, Columbus, Ohio

T. Yamanaka, Tokyo, Japan

R. A. Young, Atlanta, Georgia

AlP Production: Lin Miller, Editorial Supervisor Andrea Witt, Journal Coordinator

Kelly Quigley, Chief Production Editor
Powder Diffraction is a quarterly journal published by the JCPDS-International Centre for Diffraction Data through the American Institute of Physics (AIP). Powder Diffraction is a journal of practical technique, publishing articles relating to the widest range of application-from mineral analysis to epitactic growth of thin films and to the latest advances in software. Although practice will be emphasized, theory will not be neglected, especially as its discussion will relate to better understanding of technique.

Submit manuscripts ( 3 copies) to the most appropriate Powder Diffraction Editor listed on this page. The Editors will consider all manuscripts received, but assume no responsibility regarding them. Materials will be returned only when accompanied by appropriate postage. There is no publication charge. See Powder Diffraction Notes for Authors for additional information.

Proofs and all correspondence concerning papers in the process of publication should be addressed to: Editorial Supervisor, Powder Diffraction, AIP, Suite 1NO1, 2 Huntington Quadrangle, Melville, NY 11747-4502.

For advertising rates and schedules contact AIP Advertising Department. Orders, advertising copy, and offset negatives should be sent to: Advertising Department, American Institute of Physics, Suite 1NO1, 2 Huntington Quadrangle, Melville, NY 11747-4502; phone: (516) 576-2440; fax: (516) 576-2481.

\begin{tabular}{lcccc}
\hline $\begin{array}{l}\text { Subscription Prices } \\
\text { (2000) }\end{array}$ & U.S.A \& Canada & $\begin{array}{c}\text { Mexico, Central } \\
\text { \& South America }\end{array}$ & $\begin{array}{c}\text { Europe, Mid-East } \\
\text { \& Africa* }\end{array}$ & $\begin{array}{r}\text { Asia \& } \\
\text { Oceania* }^{*}\end{array}$ \\
\hline $\begin{array}{l}\text { Individual } \\
\text { Institutional } \\
\text { or Library }\end{array}$ & $\$ 100$ & $\$ 85$ & $\begin{array}{r}\$ 85 \\
\$ 105\end{array}$ & $\$ 105$ \\
\hline
\end{tabular}

"Subscription rates to Eastern Hemisphere include air freight service.

Back-Number Prices. 2000 single copies: $\$ 30$. Prior to 2000 single copies: $\$ 30$.

Subscription, renewals, and address changes should be addressed to AIP Circulation and Fulfillment Division (CFD), Suite 1NO1, 2 Huntington Quadrangle, Melville, Nr 11747-4502. Allow at least six weeks advance notice. For address changes please send both old and new addresses and, if possible, include a mailing label from the wrapper of a recent issue.

Claims, Single Copy Replacement and Back Volumes: Missing issue requests will be honored only if received within six months of publication date (nine months for Australia and Asia). Single copies of a journal may be ordered and back volumes are available in print or microform. Individual subscribers please contact AIP Circulation and Fulfillment Division (CFD) at (516) 576-2288; (800) 344-6901. Institutional or library subscribers please contact AIP Subscriber Services at (516) 576-2270; (800) 344-6902.

Reprint Billing: Contact: AIP Circulation and Fulfillment Division, Melville, NY 117474502; (516) 576-2230; (800) 344-6909.

Copying: Single copies of individual articles may be made for private use or research. Authorization is given (as indicated by the Item Fee Code for this publication) to copy articles beyond the use permitted by Sections 107 and 108 of the U.S. Copyright Law, provided the copying fee of $\$ 6$ per copy per article is paid to the Copyright Clearance Center, 222 Rosewood Drive, Danvers, MA 01923, USA. Persons desiring to photocopy materials for classroom use should contact the CCC Academic Permissions Service. The Item Fee Code for this publication is 0885-7156/2000 $\$ 6.00$.

Authorization does not extend to systematic or multiple reproduction, to copying for promotional purposes, to electronic storage or distribution, or to republication in any form. In all such cases, specific written permission from AIP must be obtained.

Permission for Other Use: Permission is granted to quote from the journal with the customary acknowledgment of the source. To reprint a figure, table, or other excerpt requires the consent of one of the authors and notification to AIP.

Requests for Permission: Address requests to AIP Office of Rights and Permissions, Suite 1NO1, 2 Huntington Quadrangle, Melville, NY 11747-4502; Fax: 516-576-2450; Telephone: 516-576-2268; E-mail: rights@aip.org.

Document Delivery: Copies of journal articles can be ordered for online delivery from DocumentStore, AlP's online document delivery service (http://ojps.aip.org/ documentstore/).

Reprints: Reprints can be ordered with or without covers only in multiples of 50 (with a minimum of 100 in each category) from AIP, Circulation \& Fulfillment/Reprints, Suite 1NO1, 2 Huntington Quadrangle, Melville, NY 11747-4502; Fax: 516-349-9704; Telephone: 800-344-6909 (in U.S. and Canada), or 516-576-2234.

Powder Diffraction (ISSN: 0885-7156) is published quarterly (4X annually) by the JCPDS-International Centre for Diffraction Data through the American Institute of Physics. 1999 Subscription rates: US\$105. POSTMASTER: Send address changes to Powder Diffraction, AIP Circulation \& Fulfillment Division, Suite 1NO1, 2 Huntington Quadrangle, Melville, NY 11747-4502. Periodicals postage paid at Huntington Station, NY 11746, and additional mailing offices.

Online Availability: Abstracts of journal articles published by the AIP and Member Societies (and several other physics publishers) are available from AIP's SPIN database, via AIP's Online Journal Publishing Service (OJPS) (http://ojps.aip.org).

Copyright (c) 2000 JCPDS-International Centre for Diffraction Data, 12 Campus Blvd., Newtown Square, PA 19073-3273. All rights reserved.

www.icdd.com/products/journals.htm 

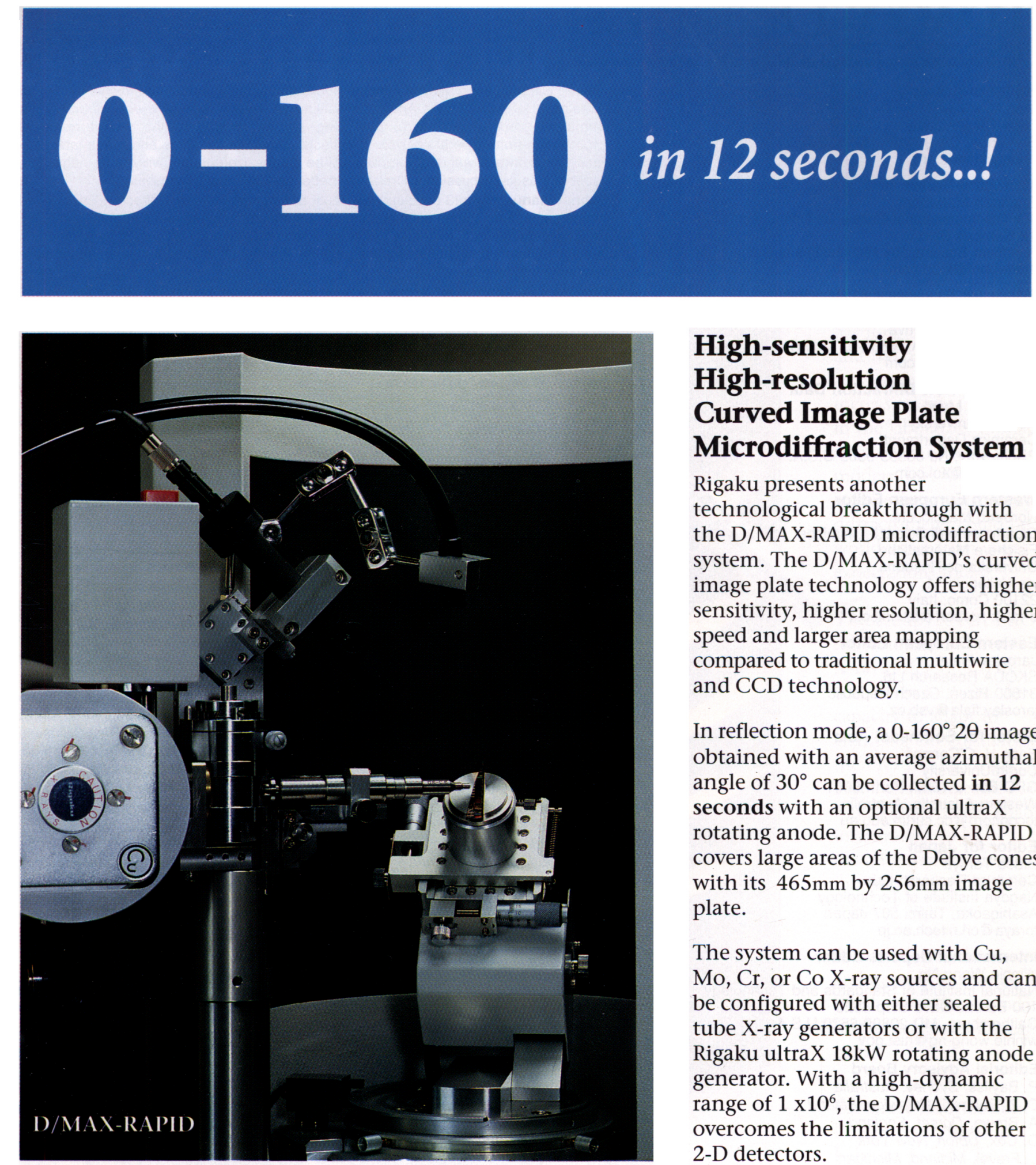

\section{High-sensitivity High-resolution Curved Image Plate Microdiffraction System}

Rigaku presents another technological breakthrough with the D/MAX-RAPID microdiffraction system. The D/MAX-RAPID's curved image plate technology offers higher sensitivity, higher resolution, higher speed and larger area mapping compared to traditional multiwire and CCD technology.

In reflection mode, a $0-160^{\circ} 2 \theta$ image obtained with an average azimuthal angle of $30^{\circ}$ can be collected in 12 seconds with an optional ultraX rotating anode. The D/MAX-RAPID covers large areas of the Debye cones with its $465 \mathrm{~mm}$ by $256 \mathrm{~mm}$ image plate.

The system can be used with $\mathrm{Cu}$, $\mathrm{Mo}, \mathrm{Cr}$, or Co X-ray sources and can be configured with either sealed tube X-ray generators or with the Rigaku ultraX 18kW rotating anode generator. With a high-dynamic range of $1 \times 10^{6}$, the D/MAX-RAPID overcomes the limitations of other 2-D detectors.

Advanced features of the D/MAX-RAPID include:

- Fast phase identification

- Polymer and fiber diffraction

- Texture and orientation

- Percent crystallinity

- Crystallite size

- Microdiffraction

- Selected-area diffraction

(Diffraction-function mapping)
- Stress

- Forensics

- Inclusions

- High-pressure diamond anvil studies

- Single crystal diffraction (with optional single crystal software/hardware package)

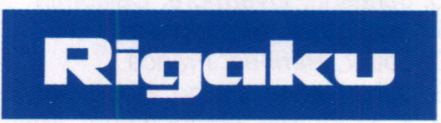

9009 New Trails Drive The Woodlands, TX 77381 Tel: (281) 367-2685 Fax: (281) 364-3628 http://www.rigaku.com/pd 


\section{TECHNICAL ARTICLES}

Anouar Njeh, Thomas

Wieder, and Hartmut Fuess

Peter Bayliss

Sergio Brückner

N. Diot,

P. Bénard-Rocherullé, and R. Marchand

W. Wong-Ng, J. A. Kaduk, Q. Huang, and R. S. Roth
Grazing excidence diffraction versus grazing incidence diffraction for strain/stress evaluation in thin films

A proposed change to determining the Pearson Symbol Code

PULWIN: A program for analyzing powder X-ray diffraction patterns

$\mathrm{X}$-ray powder diffraction data and Rietveld refinement for $\mathrm{Ln}_{6} \mathrm{WO}_{12}$

$(\mathrm{Ln}=\mathrm{Y}, \mathrm{Ho})$

Crystal structure of the monoclinic perovskite $\mathrm{Sr}_{3.94} \mathrm{Ca}_{1.31} \mathrm{Bi}_{2.70} \mathrm{O}_{12}$

\section{NEW DIFFRACTION DATA}

J. M. S. Skakle, C. L.

Dickson, and F. P. Glasser

Erich Hums

M. Y. Gamarnik, M. W.

Barsoum, and T. El-Raghy
The crystal structures of $\mathrm{CeSiO}_{4}$ and $\mathrm{Ca}_{2} \mathrm{Ce}_{8}\left(\mathrm{SiO}_{4}\right)_{6} \mathrm{O}_{2}$

X-ray powder diffraction data of a new compound $\mathrm{As}_{2} \mathrm{MoO}_{7}$

Improved X-ray powder diffraction data for $\mathrm{Ti}_{2} \mathrm{AlN}$

\section{INTERNATIONAL REPORTS}

Regional Reports

Index to Volume 15

Subject Classification Scheme Used in Volume 15 
Osmic Optics...

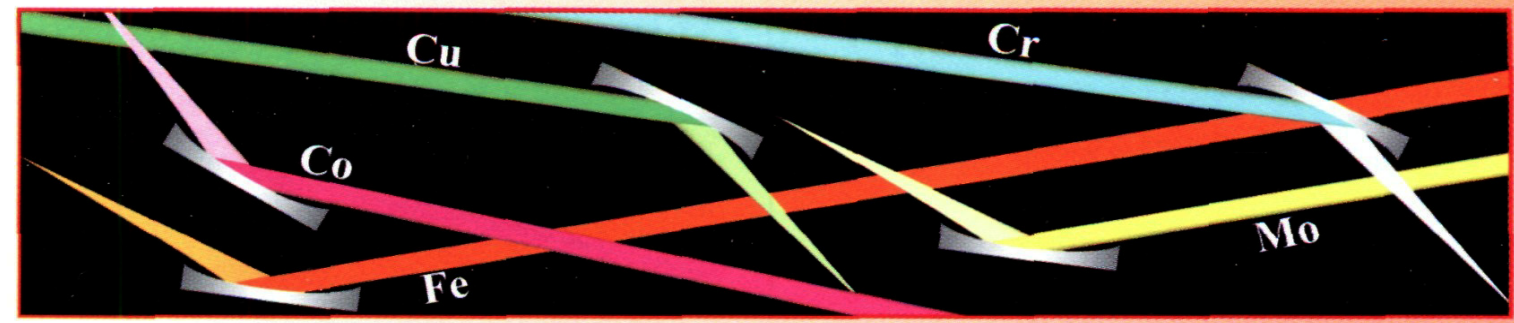

Max-Flux ${ }^{\mathrm{TM}}$

Powder
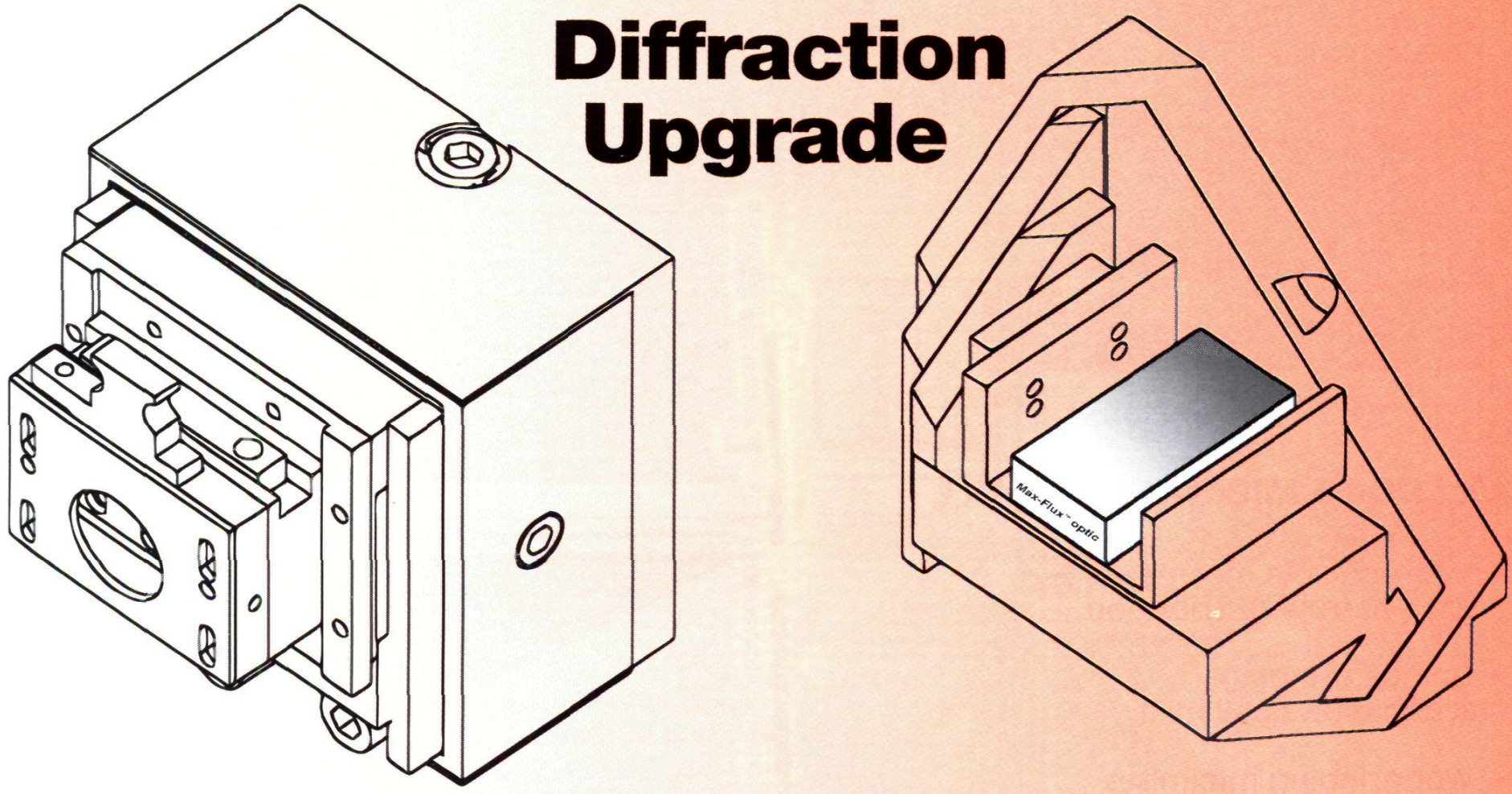

\section{Benefits}

- Reduction of sample displacement errors

- Enables testing of irregularly shaped samples

- Increased resolution

- Higher flux

- Lower background

\section{Applications}

- Thin Film Analysis

- High Resolution

- Phase Analysis

- Stress / Strain Measurements

- Texture Analysis

- Point-Defect Analysis

- And more...

Denver X-ray Conference Booth \#26

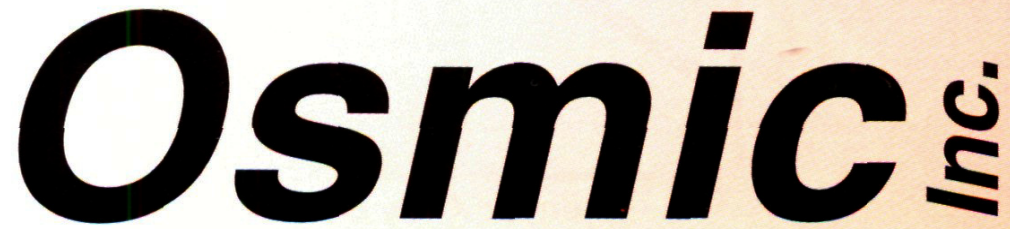

1788 Northwood Drive

Troy, Michigan 48084-5532, USA tel: 248.362.1290 fax: 248.362 .4043 


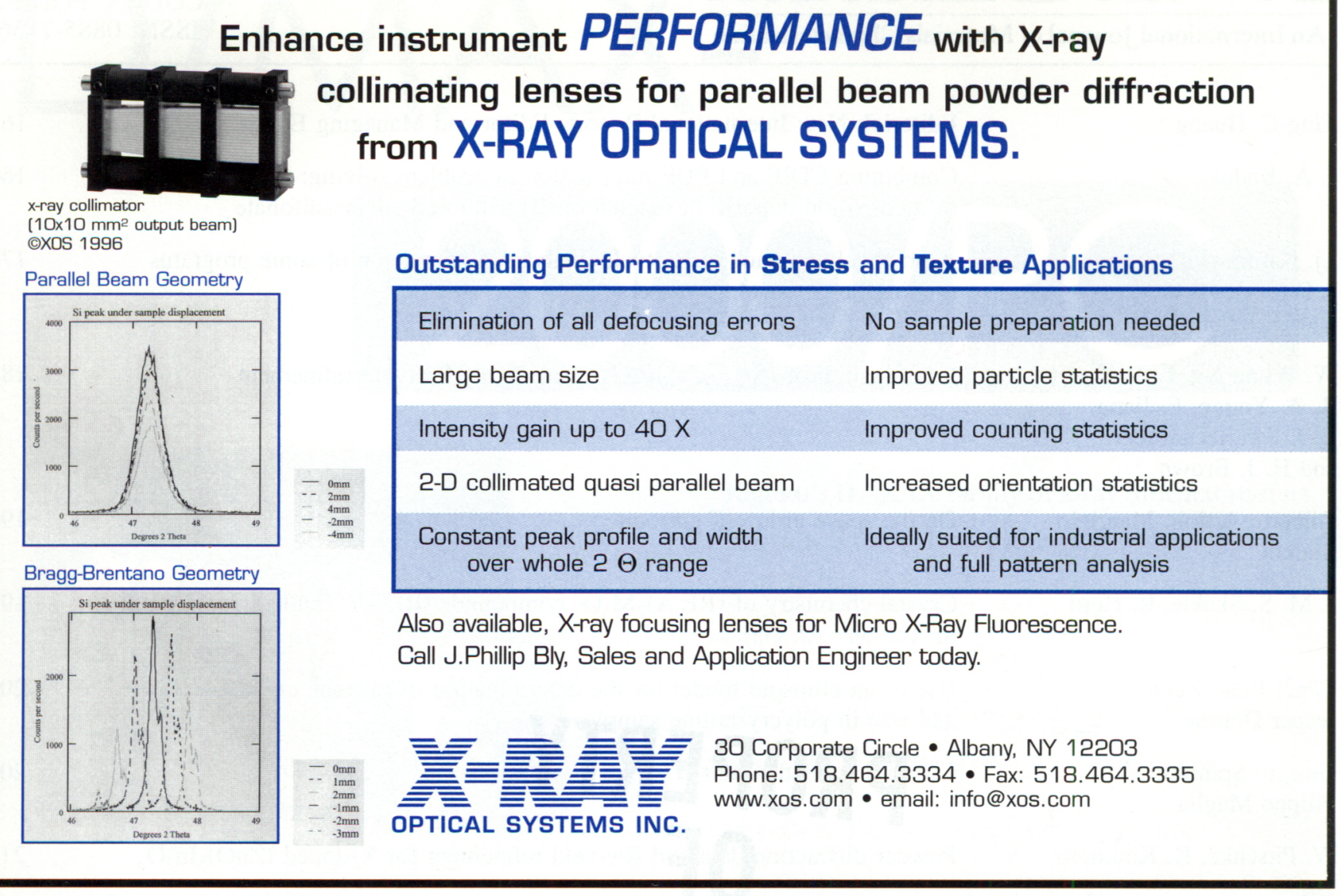

\section{Cinel Real Time XrD}

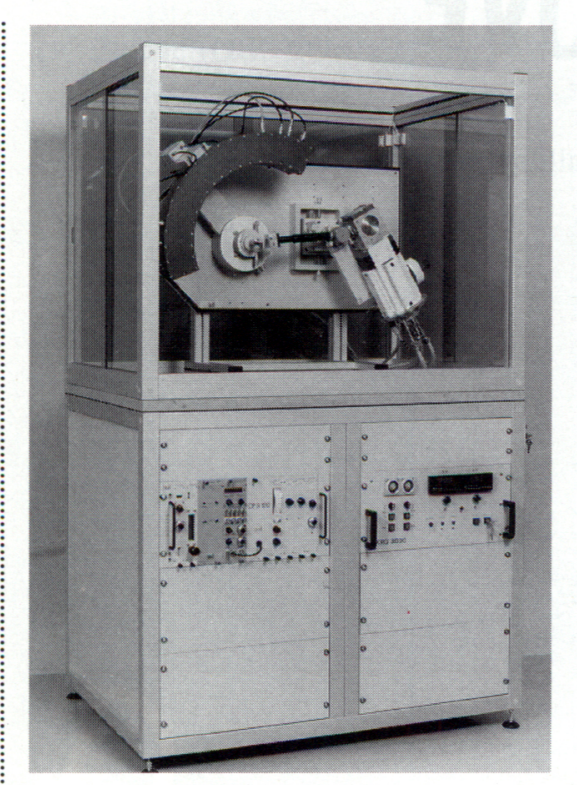

MPD Multi-Purpose X-ray Diffractometer
Versatile diffractometers designed to take advantage of the rapid, real time data collection our patented CPS X-ray detectors offer.

${ }^{*}$ No scanning feature - acquire up to $120^{\circ} 2 \theta$ simultaneously -Unique capillary devices for analysis of air sensitive materials -Identify materials even if only micro amounts are available -Parallel beam with germanium or multilayer mirror optics for information on our complete product line please contact us

inel - Z.A - CD 405 - 45410 ARTENAY (FRANCE)

Tel. (33) 0238804545 Fax. (33) 0238800814 E.MAIL: inel@valcofim.fr-INTERNET:http://www.valcofim.fr/inel

inel Inc. P.O. Box 147, STRATHAM, NH 03885 (USA) TEL. (603) 778-9161 FAX. (603) 778-9171 E-MAIL: inelinc@aol.com 


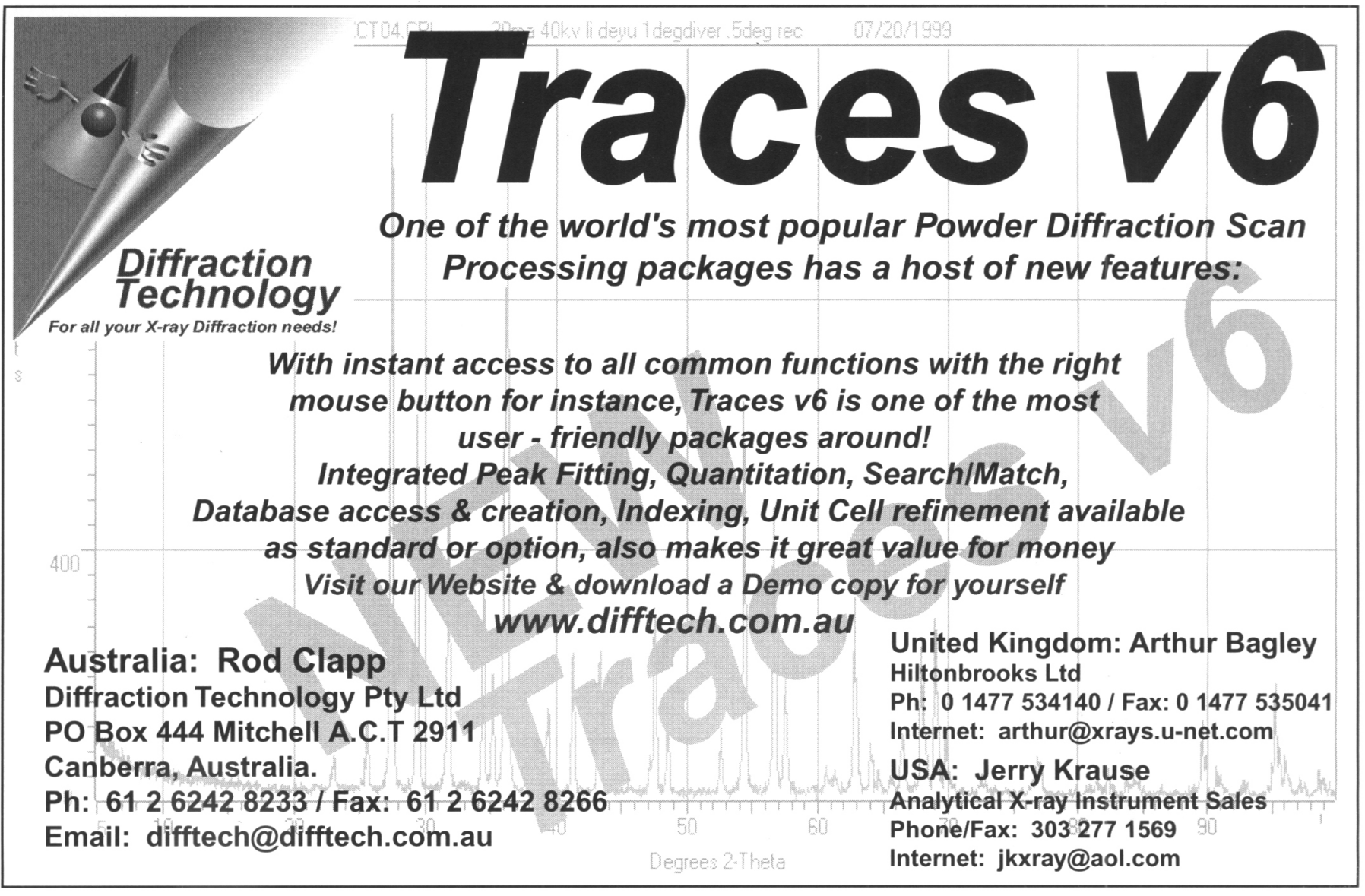

\section{Your Software For X-Ray Analysis}

Now optimized for the new, enhanced PDF database with more than 37,000 additional calculated patterns

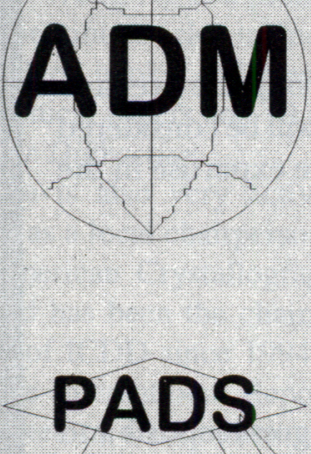

New Edition
Software package for data aquisition and analysis:

Diffractometer control, plot modules, peak search and calibration, qualitative and quantitative phase analysis, profile fitting and pattern simulation, lattice parameter refinement, crystallite size and micro stress.

Ready to plug to your PHILIPS and SIEMENS diffractometer hardware.

Stand alone package for qualitative and quantitative phase analysis.

Extremely fast search algorithms for ICDD-PDF database and user created databases. Very exact quantitative analysis using the WHOLE PATTERN method.

Extension package for most third party X-ray software. Graphicanalytical, profile-analytical and crystallographic options.

\section{a. wassermann}




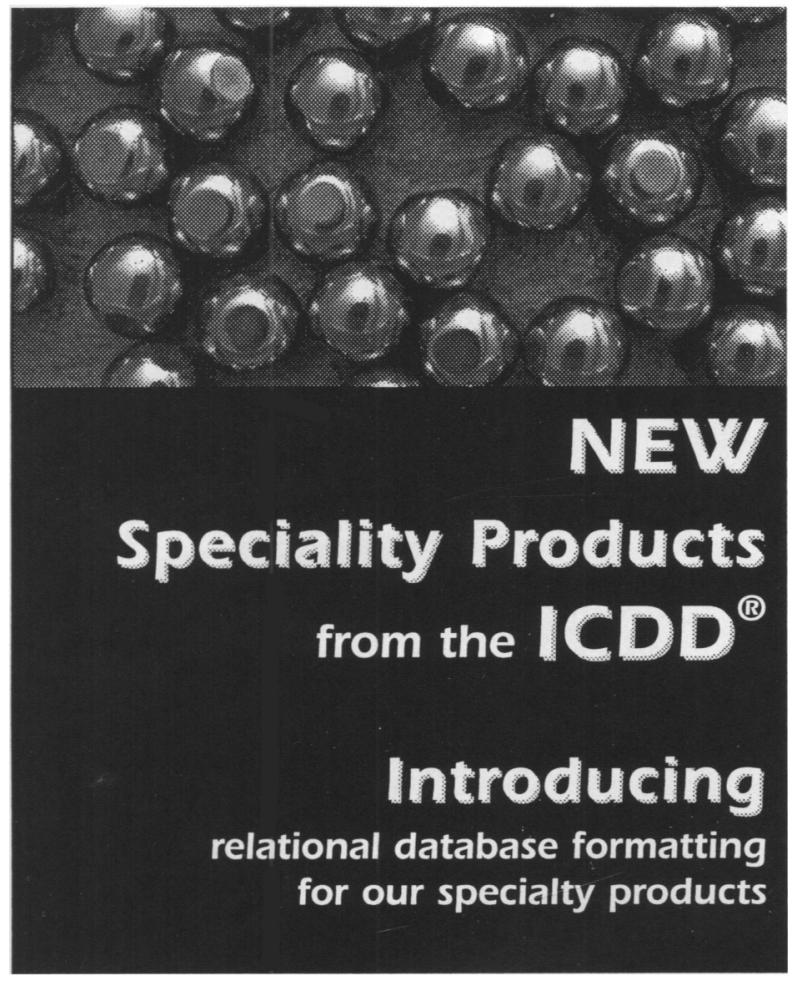

Initial RDB release-

\section{Metals \& Alloys!}

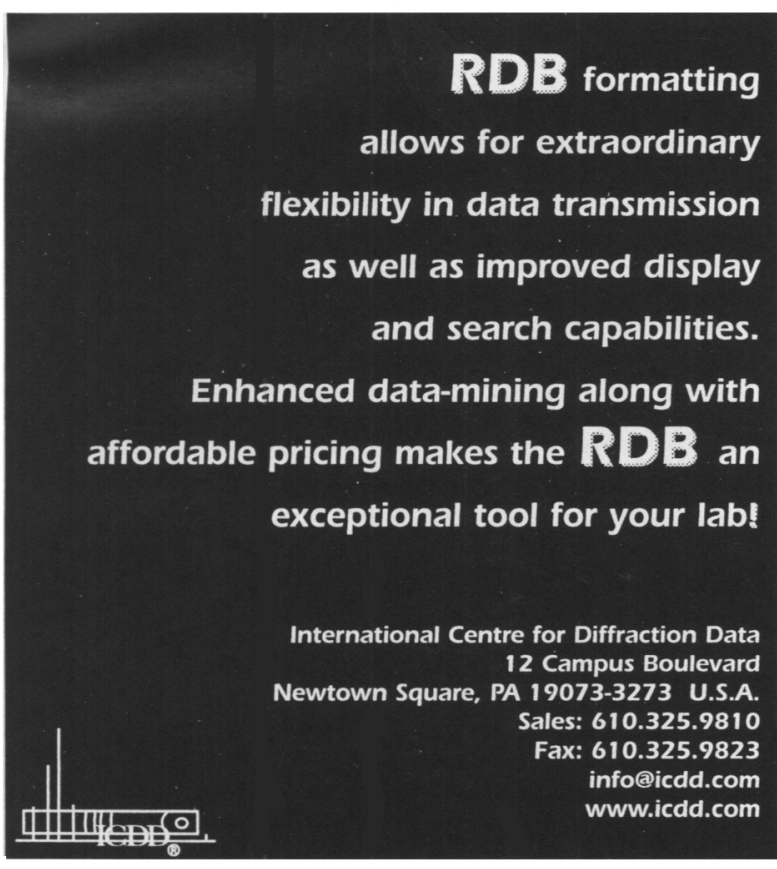

Orders may be placed on-line via: www.icdd.com/products

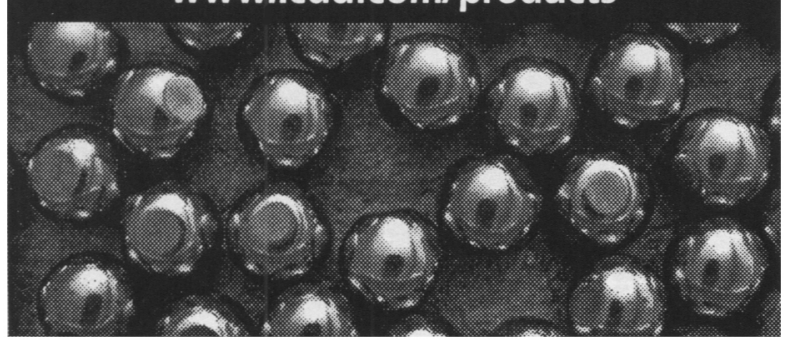

\section{Rapid particle size reduction}

\author{
for XRD, XRF and IR
}

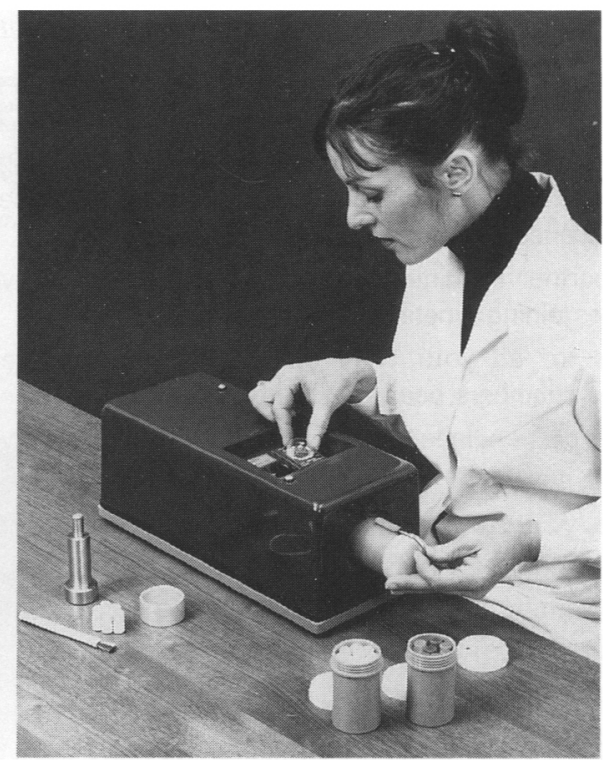

\section{MCCRONE MICRONISING MILL}

- Reproducible mean particle size - narrow distribution

- Unique grinding action (not a ball mill)

- Wet grinding minimises damage to sample crystallinity

- Choice of grinding elements (agate or corundum)

\section{Mccrone Scientific Ltd.}

Mccrone House, 155A Leighton Rd. London NW5 2RD. U.K. tel: 02072677199 fax: 02072673383 e-mail: saramark@mccronescientific.sagehost.co.uk

\section{USA Distributor:}

\section{Mccrone Accessories \& Components} 850 Pasquinelli Drive Westmont, Illinois 60559-5531 phone: 6308877100 fax: 6308877764 e-mail: MAC@mccrone.com 


\section{Get specialty beryllium prototypes with production processing in mind.}

\section{Driven to perform?}

\section{Come to us. We'll put the metal to the metal.}

When your production schedule is short, you want to get it done right the first time. You can eliminate a major uncertainty when you entrust your custom beryllium fabrication, joining and coating to us. We'll help you shine.

Here's what we can do for you:

- Depend on us as the only fully integrated source for beryllium sheet and foil products. All critical operations are performed in-house for seamless excellence.

- We're your partner in joining and coating metals. When your project involves joining a metal to a metal, you can count on us.

- Come to us for all your UHV beryllium product needs: $\mathrm{x}$-ray windows, chambers, beam pipes and more.

- Rely on our expert engineering. We like challenges. Taking your design concept into reality would be our pleasure.

Count on us for your tough jobs. Keep in mind that we're the only fully integrated source for beryllium products for the analytical, medical, and scientific industries. Challenge us with your "cutting edge" requirements. We look forward to hearing from you.

TEL: 510-623-1500 • FAX: 510-623-7600

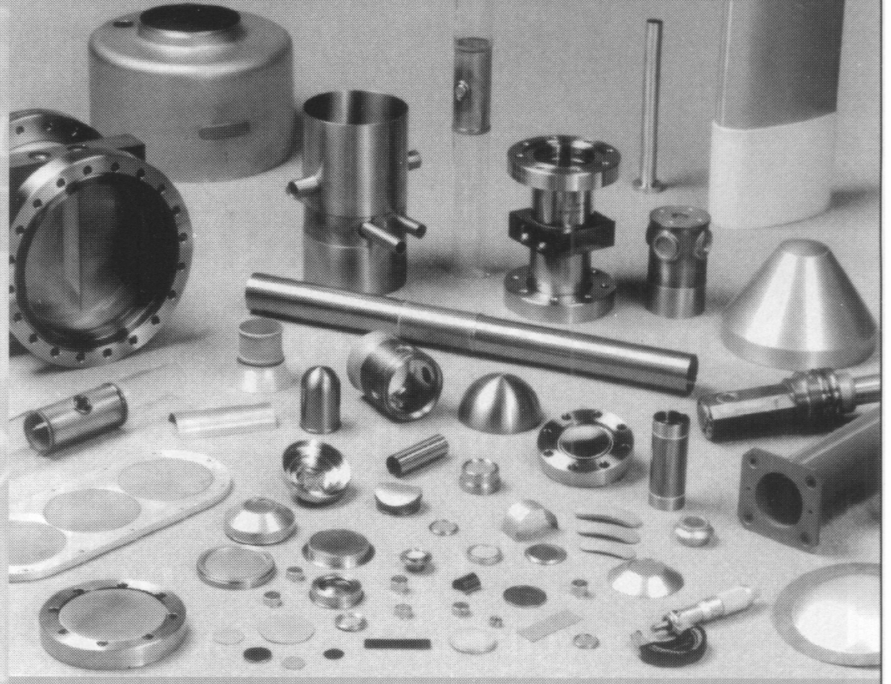

BRUSHVVELLLMAN

E-Mail:Electrofusion@BrushWellman.com

ELECTROFUSION PRODUCTS

We're the beryllium window folks.

\section{Expand your $x$-ray diffraction capabilities not your overhead.}

Whether you just need services or your XRD lab is on "overload," IC Laboratories provides every testing service and advanced capability you need in qualitative or quantitative $x$-ray diffraction analysis - from austenite to zeolites, from air filters to thin films. You are assured of rapid turn-around of results - as little as 48 hours - because IC Labs is one of the most highly automated commercial labs in the U.S., with knowledgeable personnel ready to address all your applications. For a copy of our technical prospectus, contact IC Laboratories.

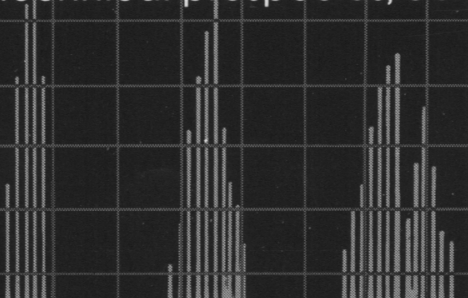

\section{IC Laboratories}

Post Office Box 721

Amawalk, New York 10501 (914) 962-2477 www.ICLABS.com 

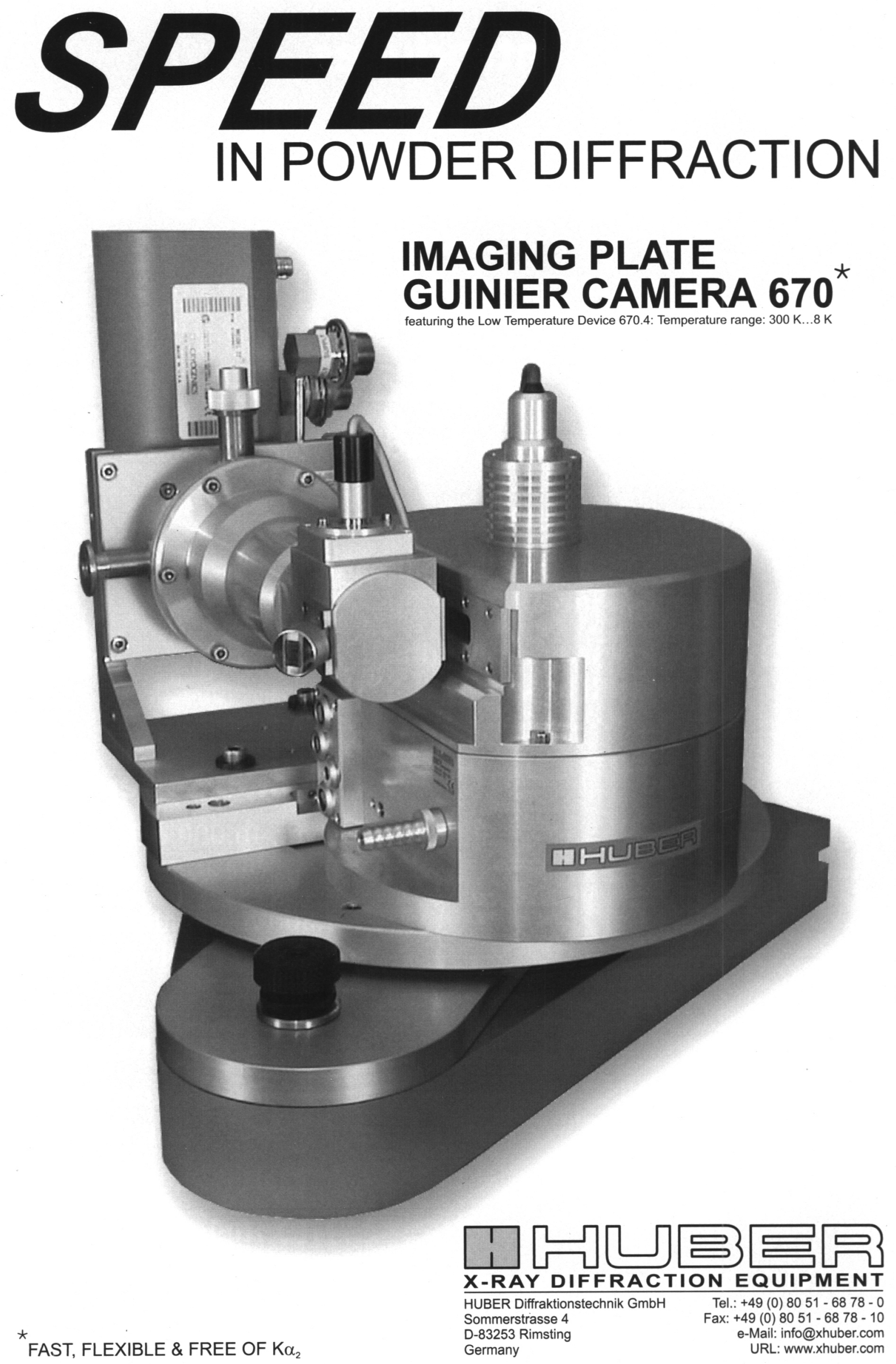
Your complete source for:

* X-ray Tubes

* Capillaries (Quartz \& Glass)

* Goniometer Heads

* Kodak ${ }^{\mathrm{TM}} \mathrm{X}$-ray film products

* Huber Components

* Complete Diffractometers

* Classical X-ray Cameras

* Custom Designs

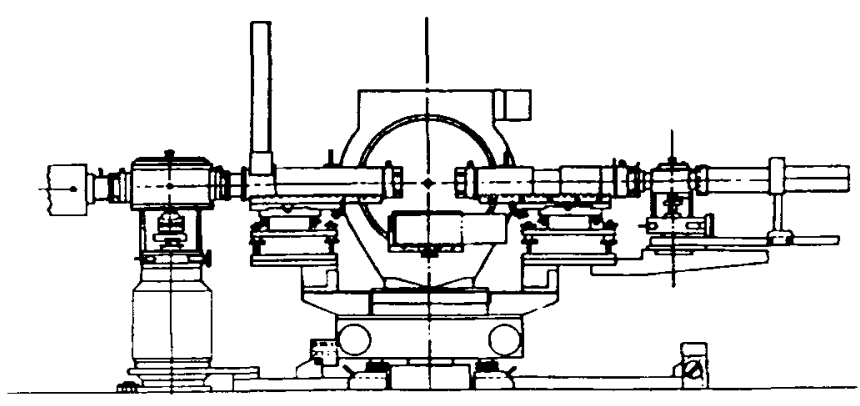

More than 4500 professionals at over 1400 research locations have chosen Blake Industries for their X-ray diffraction

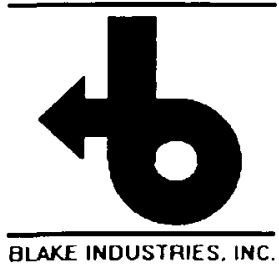
instrumentation.

Let us put our experience to work for you.

\section{Blake Industries, Inc.}

660 Jerusalem Road, Scotch Plains, New Jersey 07076 USA

Tel (908) 233-7240 - Email: blake4xray@worldnet.att.net - Fax (908) 233-1354

\section{Are You Rehdy To Rttend? 2001 ICDD $^{\circledR}$ X-ray Clinics}

\section{Learn...}

tricks of the trade, basic theory, techniques, and procedures!

Learn...

from a team of experts in the field!

\section{X-RAY FluORESCENCE SPECTROMETRY:} FUNDAMENTALS (XRFI) Advanced Methods (XRFII) 30 April - 4 May 200I 7-II May 2001
X-RAY POWDER DIFFRACTION:

FUNDAMENTALS (XRDI)

AdVANCED Methods (XRDII)
4-8 June 200I

II-I5 June 200 I

Visit us on-line at www.iedd.com

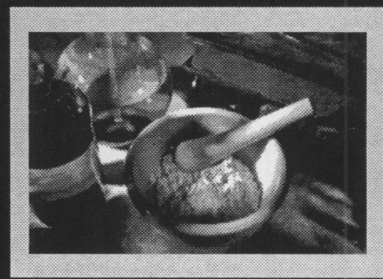

International Centre for Diffraction Data, 12 Campus Boulevard, Newtown Square, PA 19073-3273 U.S.A. $\mathrm{TCOD}{ }^{\circ}$

Tel: +610.325.9814, Fax: +610.325.9823, E-mail: clinics@icdd.com,Web: www.icdd.com 